\title{
Reguły i paradoksy
}

\section{Jean-François LYOTARD ${ }^{1}$}

\section{KEYWORDS}

postmodernism; grand narratives; language; rules; paradoxes

ACKNOWLEDGEMENT / ŹRÓDłO PRZEKŁADU

Lyotard, J.-F. (2009). Règles et paradoxes. Cabiers critiques de philosopbie, 9, 163-169².

${ }^{1}$ Jean-François Lyotard (1924-1998), francuski filozof, przedstawiciel postmodernizmu.

2 Tekst ten pojawił się w akompaniamencie Appendice svelte w pierwszym numerze Babylone zimą 1982-1983 roku pod tytutem Règles et paradoxes \& Appendice svelte, poprzedzony prezentacją. Appendice svelte był od tego czasu wznowiony w Tombeau de l'intellectuel et autres papiers, wydawnictwo Galilée, 1984. Reguty i paradoksy (fr. Règles et paradoxes) „składa się z notatek sporządzonych w oparciu o referat wygłoszony w rzymskim Teatro, w ramach konferencji dotyczącej «Paysage Métropolitain», zorganizowanej przez Giuseppego Bartolucciego 18 lutego 1981 roku". Notatki te zostały przetłumaczone i opublikowane przez Maurizia Ferrarisa w Alfabeta (24 maja 1981), następnie ponownie przetłumaczone na francuski przez Philippe'a Duboya dla dossier zatytułowanego L'architecte dans le débat moderne. I. Le postmodernisme oraz zredagowane przez Jeana-François Lyotarda (zob. Babylone 19821983: 68). Dziękujemy Dolores Lyotard za nadzór nad sporządzeniem tekstu. 
Nie będę tutaj robił wykładu, chciałbym jedynie zdefiniować kilka ważnych pojęć. Po pierwsze „postmodernistyczny” jest prawdopodobnie bardzo złym terminem, ponieważ sugeruje „periodyzację” historii, otóż „periodyzacja” jest pojęciem „klasycznym” lub „modernistycznym”. „Postmodernistyczny” oznacza po prostu stan duszy lub - lepiej - stan umysłu. Można by rzec, że chodzi tutaj o zmianę stosunku do problemu znaczenia: powiedziałbym, znacząco upraszczając, że nowoczesność oznacza świadomość braku wartości w wielu działaniach. Jeśli pragniemy tego, co nowoczesne, oznacza to, iż niemożliwe staje się udzielenie odpowiedzi na pytania o sens. Romantyzm, jako brak sensu i świadomość tego braku, jest modernistyczny, a także coś takiego jak dandyzm, czy to, co Friedrich Nietzsche nazywa „aktywnym nihilizmem”, który jest nie tylko świadomością utraty sensu, ale i ożywieniem tej straty.

Po drugie modernizm próbował dostarczyć filozoficznej, a zarazem politycznej odpowiedzi na dandyzm i romantyzm, to znaczy próbował stworzyć coś, co można by nazwać „wielką narracją”, którą odnaleźć można albo w narracji o emancypacji, począwszy od rewolucji francuskiej, albo w dyskursie na temat realizacji Rozumu w myśli niemieckiej. Istnieje również narracja o bogactwie, czyli o ekonomii politycznej kapitalizmu. Wszystkie te teksty zostały w pewien sposób zreorganizowane i wzmocnione przez marksistowską narrację, która zajmowała scenę filozoficzną i polityczną Europy i świata przez cały wiek.

Moja hipoteza robocza brzmi, iż dla dużej części współczesnych społeczeństw narracje te nie są już wiarygodne i nie wystarczają, by zagwarantować - co usiłowały zrobić - spoiwo polityczne, społeczne czy kulturowe. Znajdujemy się w sytuacji, w której nie mamy do nich zbyt wiele zaufania. Musimy stawić czoło problemowi sensu bez możliwości udzielenia odpowiedzi poprzez nadzieję na emancypację ludzkości, jak w przypadku szkoły oświeceniowej, lub emancypację ducha, jak w przypadku idealizmu niemieckiego, nie pokładamy też już nadziei $\mathrm{w}$ działaniach proletariatu zmierzających do utworzenia przejrzystego społeczeństwa. Nawet kapitalizm, dyskurs liberalny czy neoliberalny, wydaje mi się mało wiarygodny w obecnej sytuacji: nie oznacza to, iż kapitalizm się skończył, wręcz przeciwnie, jednakże nie znajduje on już uzasadnienia. Dawna argumentacja: „wszyscy się wzbogacą” nie jest już przekonująca.

Dzisiaj kapitalizm wykorzystuje siłę, którą dotąd lekceważył, to znaczy język. Robi to dzięki rozwojowi nie tylko mediów, ale i technik informacyjnych w perspektywie informatyzacji społeczeństwa jako całości, czyli wszystkich rodzajów komunikacji, które mają znaczenie dla społeczeństwa. Taka jest dzisiaj kapitalistyczna perspektywa i jasne jest, że dzięki niej kapitalizm wyjdzie z kryzysu.

Doświadczenie, jakie mam z mediami, jest nieznaczne. Sądzę jednak, że tylko frazy przetłumaczalne na język informacyjny zostaną wzięte pod uwagę. Kiedy usiłujemy mówić za pośrednictwem mediów w inny sposób, wytyka się nam brak klarowności oraz zawiłość (dyrektor dużego francuskiego dziennika 
odpowiedział awangardowemu redaktorowi, który skarżył się na to, że w owym dzienniku nie ma krytyki jego książek: „Proszę mi przesłać książki, które potrafią być komunikatywne”). Znajdujemy się już w sytuacji, w której zdanie musi odpowiadać wymaganiom logiki informacyjnej.

Logika ta jest relatywnie prosta: należy umieć przepisać zdanie, nawet złożone, w takiej formie, żeby można było wymienić jednostki informacji. To znaczy, według logiki binarnej pochodzącej z algebry Boole'a: tak/nie, pod tym warunkiem język może się stać towarem, że jego sens stałby się możliwy do zaksięgowania. Jeśli chcecie państwo, by wasze zdania krążyły po językowym rynku (który jest przede wszystkim rynkiem mediów), muszą one być konkurencyjne. Zdania, o których nie będziemy mogli powiedzieć: „oto informacja zakomunikowana”, nie będą zaksięgowane i co za tym idzie, nie zostaną zakomunikowane.

Sądzę, że fraza naukowa, artystyczna lub filozoficzna nie nadaje się do prostej transmisji informacji. Wielu próbowało przepisać dane, zwłaszcza filozoficzne, na język maszynowy, jednak bez skutku. Oznacza to, że tego typu języki analizowane z punktu widzenia ich wydajności oceniane są jako niespójne.

Prawdziwy problem polega zatem na ustaleniu, czy język jest naprawdę środkiem, i to środkiem komunikacji. Podstawowym założeniem pracy artysty, filozofa lub uczonego jest fakt, iż język takim środkiem nie jest: zgodnie z ich wspólnym założeniem jest on sam w sobie autonomiczny, oraz iż ich zadaniem jest rozszyfrowywanie jego sekretów.

Podam prosty przykład. Gdy Sigmund Freud napisał Traumdeutung, zasugerowat, iż istnieje pewien rodzaj języka nieświadomości, oraz zdefiniował lub starał się zdefiniować operatory tegoż języka, to znaczy przemieszczenie i kondensację. Efektem tych operatorów jest tworzenie zdań niezrozumiałych, niemożliwych do zakomunikowania w przejrzystym języku. Jednocześnie niektórzy lingwiści, oraz częściowo Jacques Lacan, twierdzili, iż nieświadomość mówi pewnego rodzaju językiem; próbowali oni udowodnić, iż jej operatory były takie same jak w języku.

Uważam, że jest to błąd oraz że język nieświadomości istnieje tylko wtedy, gdy używa on operatorów innych niż te ze zwykłego języka, a przemieszczenie i kondensację należy rozumieć inaczej niż poprzez model zwyczajnych operatorów językowych. Operatory snu nie są tajemnicze, sądzę, iż Freud zaczął je opracowywać.

Stajemy wobec bardzo starej dyskusji toczonej w filozofii świata Zachodu. Między Arystotelesem a sofistami problem polegał na ustaleniu, czy język, opierając się na konkretnych operatorach, jest w stanie wytworzyć zdania niespełniające w całkowicie dziwny sposób jego standardów. Zdania te nazwano paradoksami, a operatory paralogizmami. Wszyscy językoznawcy i logicy wiedzą, że język jest zdolny do paradoksów i paralogizmów.

Jeśli chodzi o pracę naukową lub artystyczną, zdajemy sobie sprawę z tego, że problem się nie zmienia i polega nadal na wytwarzaniu zdań paradoksalnych. 
Nauka używa języka pisanego, w sztuce z kolei frazy są chromatyczne, złożone z form, dźwięków, objętości, jednak można je z całą pewnością uznać za frazy, to znaczy artykulację oddzielnych (dyskretnych) elementów. Z wszystkich tych powodów praca artysty czy uczonego polega jedynie na wyszukiwaniu operatorów, które są w stanie wytworzyć frazy, jakich jak dotąd nie słyszeliśmy i jakie z definicji - przynajmniej za pierwszym razem - są zatem niemożliwe do zakomunikowania. Frazy te staną się komunikowalne, kiedy operatory, które pozwalają je wytworzyć, będą znane przez adresata i gdy adresaci będą w stanie je ponownie przepisać.

Gdyby na przykład przeanalizować prace Marcela Duchampa, widać wyraźnie, że problem polega na tym samym: bierzemy elementy plastyczne, a niekiedy również językowe, poddajemy je transformacjom za pomocą konkretnych operatorów i podajemy rezultat operacji bez wyjawiania ich natury. Odbiorca pozostaje tym samym zdziwiony i niezadowolony: śmieje się lub protestuje, wiadomości są bowiem niezrozumiałe. Praca fizyków końca ubiegłego stulecia niczym się od tego nie różniła: uznawano, że masa stanowi jedno, a szybkość drugie, aż do momentu, kiedy ktoś powiedział, że jedno jest od drugiego zależne.

Praca ta dotyczy operatorów, to znaczy zasad, których przestrzegają dzieła naukowe i artystyczne. Tworzy więc ona dzieła koniecznie dziwne, których zadaniem jest wyłącznie eksperymentowanie z regułami. Największy problem stwarzają teraz reguty.

To samo tyczy się polityki, a my wszyscy jesteśmy politykami — nie wiedząc zresztą, co to takiego właściwie oznacza. Myślimy, że wymiana zdań w życiu codziennym musi przestrzegać pewnych regut, że zdania mają operatory, że te operatory są już ustanowione i że w przypadku nieobecności operatorów i reguł komunikacji wpadamy w anarchię. Tradycja demokratyczna mówi, że wszyscy odbiorcy zdań mogą zgodzić się co do pewnej ich liczby wymienianej w społeczeństwie. Weźmy na przykład zdanie: „Pewnej ilości pracy słusznie należy się pewne wynagrodzenie". Ten model, będący niczym innym jak dzisiejszą formą kontraktu społecznego, nie jest już wiarygodny z powodu, który wyjawia pewną ważną, niekoniunkturalną trudność: mowa zawiera gry zdań, które podlegają różnym zasadom. Jeśli na przykład powiem: „Ten mur jest biały”, jest to zdanie opisowe, a osoba, która mnie słucha, odpowie mi tak lub nie. Zdanie to stawia więc odbiorcę w pozycji, z której zmuszony jest on zgodzić się z nim lub, w odwrotnym przypadku, odpowiednio umotywować swą odmowę.

Jeśli jednak powiem komuś: „Nie pracuj pięćdziesięciu godzin tygodniowo”, jest to zdanie, które nie odpowiada żadnym regułom prawdziwości. Odbiorca nie ma odpowiedzieć tak lub nie, jak gdyby chodziło o opis. Problemem dla niego nie jest to, czy mówię prawdę, czy kłamię, lecz czy ma mnie usłuchać, czy nie. Jeśli usłucha, znaczy to, iż uważa mój rozkaz za słuszny (a nie nieprawdziwy) oraz uznaje mnie za uprawnionego do wydania mu go. Sprawiedliwość czy władza nie grają roli, kiedy mowa o prawdzie. 
Podam przykład nieco bardziej dramatyczny: ludzie z mojego pokolenia we Francji zderzyli się z problemem wojny algierskiej. Po dość prostej analizie sytuacji łatwo można było zrozumieć, że rozwój działań zbrojnych po stronie algierskiej i uzyskanie niepodległości doprowadziłyby do powstania reżimu biurokratyczno-militarnego, który specjalnie demokratyczny by nie był. Jest to opis, który mógłby dać asumpt do zgody lub odmowy. Wnioski, jakie moglibyśmy wyciągnąć z pierwszej hipotezy, byłyby takie, by w żaden sposób nie wspomagać niepodległości Algierii. Byłoby to jednak nieporozumieniem, iluzją: nie możemy bowiem wysnuć zaleceń (nawet tych negatywnych) z jakiegoś opisu. Można by istotnie stwierdzić, co też uczyniono: ,jest prawdą, że ruch ten stworzy aparat biurokratyczno-militarny, słu s z ne jest jednak poprzeć o ile nie aparat militarny, to chociaż sam ruch”. Innymi słowy, namacalnie doświadczamy tego, co polityczne, z czym mamy do czynienia codziennie: są dwie rodziny zdań - jedna przestrzega reguł prawdy i fałszu, druga reguł sprawiedliwości i niesprawiedliwości. Rodziny te są od siebie niezależne i nie ma możliwości przełożyć jednej na drugą.

Cała tradycja zachodnia uważa, że to, co słuszne, pochodzi o tego, co prawdziwe. Teraz jednak wiemy, że to nieprawda. Nawet w języku codziennym istnieją rodziny zdań, które przestrzegają operatorów i reguł niedających się przetłumaczyć jedne na drugie. Języki są przetłumaczalne (na przykład można przetłumaczyć francuski na włoski), ale zdanie, które coś zaleca, nie jest bezpośrednio przetłumaczalne na zdanie, które coś o pisuje. Dlatego też wewnątrz języka istnieje pewna nieprzejrzystość.

Mógłbym ewentualnie powiedzieć, że język nie komunikuje się ze samym sobą: może tworzyć zdania nieprzetłumaczalne na inne zdania. Właśnie to stanowi przeszkodę w kontrakcie, albowiem zakładamy z góry, że możemy osiągnąć całkowitą przejrzystość językową tego, o czym akurat mówimy. Zatem stając przed próbą zredukowania mowy do przetargowej informacyjnej jednostki, która powinna być $\mathrm{w}$ stanie przetłumaczyć każde zdanie, myślę, że - z braku legitymizujących narracji - pozostaje nam tylko jedna możliwość: walczyć na rzecz tej niekomunikatywności, to znaczy artykułowania możliwości nowych zdań.

Walkę tę prowadzą głównie artyści. Tym, co ważne w sztuce, jest właśnie tworzenie dzieł, w których reguły je stanowiące zostały przebadane wewnątrz tego dzieła. Nie potrzeba teorii, by to zrobić. Powiedziałbym nawet, że lepiej, żeby jej nie było.

We Francji i w Stanach Zjednoczonych - nie wiem, jak jest we Włoszech - rozwinął się niedawno ruch reakcyjny, wychwalający powrót do łatwo rozpoznawalnych i komunikatywnych form dzieł, odpowiadających wymaganiom rynku - nie tylko finansowego, ale rynku mediów, to znaczy rynku komunikacji. Wynika to zapewne z faktu, że trudno dziś artystom schować się za teoriami (marksistowską, semiotyczną lub wywodzącą się z Freuda). Teoriami, 
które w latach sześćdziesiątych i siedemdziesiątych ubiegłego wieku miały za zadanie uzasadniać paradoksy przedstawiane $\mathrm{w}$ dziełach. Te teorie wywodzące się z nauk humanistycznych tracą dziś na wiarygodności. Uważam to za słuszne. Oznacza to bowiem, że artyści nie chcą, nie mogą być już chronieni argumentami teoretycznymi: stosunek pomiędzy krytykiem i artystą zmienił się - krytyk przestał rozumieć, treść (argument) dzieła nie jest mu już podana. Mówi on: „dajcie mi coś komunikatywnego”. Sądzę, że sporo artystów ulega dziś temu okropnemu wymogowi, w przeciwnym wypadku są oni zobowiązani do robienia tego, co robią, nie będąc pod ochroną argumentów teoretycznych, które stanowią według mnie tylko argumentację ideologiczną, zapożyczenie $\mathrm{z}$ nauk humanistycznych, to znaczy typ dyskursu, który jest w istotnym stopniu związany z niezbędnym mu systemem społecznym.

$\mathrm{Na}$ koniec dorzucę, że dyskurs filozofa zawsze polegał na znalezieniu reguły jego własnego dyskursu. Filozof jest więc kimś, kto mówi, aby znaleźć regułę tego, co chce powiedzieć, a zatem mówi, „zanim” ją pozna, nie znając jej. Myślę, że sytuacja ta jest porównywalna do sytuacji artystycznych awangard i, częściowo, nauki. Od pewnego czasu artyści (myślę tutaj o Cézannie, ale dziś jeszcze częściej) szukają takich reguł, aby ich dzieła mogły być uważane za, na przykład, malarskie. Im dalej się posuwamy, tym bardziej rozumiemy, że w tradycji tego, co zwiemy „malarstwem”, znajduje się niesamowita ilość przeciwieństw. Artysta jest tym, który odkrywa w swoim dziele i poprzez nie pewien dotychczas niezbadany aspekt regut. W tym sensie pracuje on $\mathrm{i}$, wobec tego, pracował jako filozof.

\footnotetext{
* Mgr filologii francuskiej Uniwersytetu Jagiellońskiego.

** Student zarządzania Uniwersytetu Jagiellońskiego.
} 